\title{
Australian Journal of

\section{Trait association for improved grain yield of extra-early maturing maize hybrids evaluated in the forest and transitional zones of Ghana}

\author{
G.B. Adu ${ }^{1 *}$, R. Akromah ${ }^{2}$, M.S. Abdulai ${ }^{1}$, K. Obeng-Antwi ${ }^{3}$, H. Alidu ${ }^{1}$, K.M.L. Tengan ${ }^{3}$ \\ ${ }^{1}$ CSIR-Savanna Agricultural Research Institute, Nyankpala, Tamale, Ghana \\ ${ }^{2}$ Department of Crops and Soil Sciences, Faculty of Agriculture, Kwame Nkrumah University of Science and \\ Technology, Kumasi, Ghana \\ ${ }^{3}$ CSIR-Crops Research Institute, Kumasi, Ghana
}

* Coresponding author: gbadu@ csirsari.org; gloriaboakyewaa@yahoo.com

\begin{abstract}
The present study used sequential path analysis and factor analysis to determine the interrelationship between grain yield and other agronomic traits of 100 extra-early maturing maize genotypes. The objective was to identify traits with the greatest influence on grain yield for use as selection criteria in future breeding programmes. The coefficient of correlations revealed that grain yield correlated positively with ear aspect, days to anthesis, days to silking, plant height, and number of ears harvested per plot and plant stand. Grain yield was however, negatively correlated to husk cover and ear number per plant. Path analysis identified plant height and number of ears harvested per plot to have a positive direct effect on grain yield while ear number per plant had a negative direct effect on grain yield. Also, plant stand, number of ears harvested per plot and ear aspect were identified to have the greatest influence on yield by factor analysis.
\end{abstract}

Keywords: Correlation; factor analysis; multiple traits; path analysis; Zea mays.

Abbreviations: ASI_ anthesis-silking interval; DA_ days to anthesis; DS_ days to silking; EA_ ear aspect; EH_ ear height; EHARV_ number of ears harvested per plot: $\mathrm{EPP}_{-}$ear number per plant; $\mathrm{GY}_{-}$grain yield: $\mathrm{HC}_{-}$husk cover; $\mathrm{n}_{-}$sample size; PH_ plant height; $P S_{-}$plant stand: $R_{\text {_ }}$ root lodging; $\mathrm{R}_{\text {_ }}$ residual; $\mathrm{R}_{\text {_ }}^{2}$ coefficient of determination; $\mathrm{SL}_{-}$stalk lodging.

\section{Introduction}

Maize is one of the most important crops for the agricultural sector and for food security of Ghana. It is the number one crop in terms of area planted and accounts for $50-60 \%$ of total cereal production (MiDA, 2010). Annual maize production in the country has increased at an estimated rate of $4.95 \%$ per annum from 2000 to 2014 at a yield of $1.74 \mathrm{t}$ $\mathrm{ha}^{-1}$ (MoFA, 2013; Index Mumdi, 2015). This is quite low compared to the world average yield of $5 \mathrm{t} \mathrm{ha}^{-1}$ (FAOSTAT, 2014). The marginal increase in production over the last decades has come as a result of expansion in the area harvested rather than from increases in yield per unit area. The area harvested has increased steadily from 7 to 10 million hectares from 2000 to 2014 (Index Mumdi, 2015). Increasing production through expansion in the area of land harvested cannot be sustainable given the increase in the demand for agricultural land for other activities per crop in response to population increase. Therefore, it is of great importance to adopt improved technologies to maximize yield. Maize grain production, the primary trait of interest of most breeding programmes is the final outcome of a combination of different plant structures and their interactions with the environment. Since grain yield is quantitatively inherited, it is more difficult to predict than other traits. Thus, grain yield is often partitioned into components or traits that have explanatory value for predicting grain yield (Ross, 2002). Also, the use of secondary trait with grain yield, rather than selection for grain yield alone, has been shown to increase selection efficiency in maize grown under stress by 20 to $50 \%$ (Bänziger and Lafitte, 1997; Edmeades et al., 1997; Chapman and Edmeades, 1999). Traits such as number of grains per row; 100-grain weight, cob diameter, plant height, ear weight and ear length, are commonly used to predict grain yield (Ross, 2002; Mohammadi et al., 2003; Maman et al., 2004; Samonte et al., 2006). Yield related traits such as biomass, harvest index, plant architecture, and resistance to biotic and abiotic constraints may also indirectly affect yield by affecting the yield component or by other unknown mechanisms (Quarrie et al., 2006). In maize, effective improvements in grain yield have been achieved through the use of selection indices involving useful secondary traits under diverse environments (Edmeades et al., 1998; Menkir and Akintunde, 2001; Badu-Apraku et al., 2003; BaduApraku, 2011). Generally, selection based on an index, which is a function of multiple traits that are under selection allows the breeder to consider the mutual effects of several traits on yield at the same time, rather than the independent effects of the individual traits involved. The reliability of a selection index, however, depends greatly on the relative significance of the contribution of each trait on the formation of yield. As the number of traits under consideration in a breeding programme increases, it becomes challenging to determine which traits are most important to yield improvement. In this case, a breeder's in-depth knowledge of interrelationships between grain yield and its contributing components can significantly improve the efficiency of the breeding 
programme through the use of appropriate selection indices (Mohammadi et al., 2003).

A review of other research indicates a special importance to determining relationships between yield and its components and also emphasizes on, the type of germplasm used, environmental variations and applied statistical analyses used in this kind of study ultimately influence the results, interpretations and conclusions drawn (Kumar and Kumar, 2000; Mohammadi et al., 2003; Fakorede et al., 2011; BaduApraku et al., 2012; Filipovic et al., 2014). Statistical analyses commonly used to study the existing relationships among traits in crop science include simple correlation analysis, linear regression, factor analysis and path analysis (Mohammadi et al., 2003; Badu-Apraku et al., 2012; Filipovic et al., 2014). Simple correlation studies measures the degree of association between two random variables independent of other variables to be considered. Thus, when a large set of variables are involved, this method does not indicate the real interrelationship as the mutual-interference between the individual variables are not considered (Bhatt, 1973). Also, correlation coefficient, the main product of correlation studies simply measures the linear relationship between two variables without providing any information on the cause and effect of such relationships (Abozary, 2002). Path coefficient analysis allows the separation of correlation coefficient into direct and indirect effects (effects exerted through other variables) through a standardized partial regression analysis of a closed system of linearly related variables (Wright, 1921). The aim of path coefficient analysis is to present an appropriate interpretation of correlation between variables, by creating cause and effect models (Solymanzadeh et al., 2007). However, most path analysis investigations ignore the importance of the causal relationships but usually use a model in which the bidirectional causation among variables is assumed. This conventional path analysis approach might result in multicollinearity, particularly when predictor variables in the model are highly correlated with other predictor variables (Hair et al., 1995). Multicollinearity can cause strange results when attempting to study how well individual predictor variables contribute to an understanding of the dependent variable as the effects of the predictor variables are usually confounded and this may lead to incorrect conclusion of the relationship between independent and dependent variables (Sharma, 1996; Hoe and Kim, 2004). To address this issue, sequential path analysis has been widely used by researchers for determining the relationship between yield and related traits in maize (Agrama, 1996; Mohammadi et al., 2003; Badu-Apraku et al., 2012) and in other crops such as rice (Samonte et al., 1998; 2006) and sorghum (Maman et al., 2004; Ezeaku and Mohammed, 2006).

As a multivariate statistical technique, factor analysis is used to examine the interrelationships among a set of variables with a view to selecting a few of those variables that might influence further responses on other variables. Even though most explanatory variables in biological sciences tend to correlate, relationships between yield components can be different, from absence of significant relationship to almost functional relationship and interaction in compensatory patterns (García Del Moral et al., 2003). In cases where yield components are suspected to interrelate in a complex fashion, factor analysis may be used to untangle the linear relationships into their separate patterns and also define how the patterns overlap by revealing traits that are involved in more than one pattern. Each pattern will appear as a factor delineating a distinct cluster of interrelated traits, factors identified then represent the causes of the patterns they represent (Rummel, 1970) thereby providing a better understanding of the background structures of yield components as well as their contributions to the formation of principal factors that define yield. This study was aimed at using sequential path analysis and factor analysis to (1.) Determine the interrelationships among grain yield and other agronomic traits of 100 extra-early maturing maize hybrids and (2.) Identify traits with the greatest influence on grain yield for use as selection criteria in future breeding programme.

\section{Results and Discussion}

\section{Analysis of variance}

The combined analysis of variance showed the differences among environments (E) and genotypes $(\mathrm{G})$ to be significant $(\mathrm{P} \leq 0.05)$ for almost all traits measured, except for ear number per plant for genotypes. Also, genotype by environment interactions ( $\mathrm{G} \times \mathrm{E}$ ) were found to be significant $(\mathrm{P} \leq 0.05)$ for almost all traits measured, except for anthesissilking interval, grain yield, plant height, root lodging and plant stand (Table 1). These results indicated the presence of variability among genotypes, environments, and also the stability in the genotypic expression of anthesis-silking interval, grain yield, plant height, root lodging and plant stand across the test locations. The magnitude of environmental mean squares observed was higher than genotypic mean squares for all the traits under study (Table 1), indicating great influence of environment on these traits. This result is in agreement with the findings of Badu-Apraku et al. $(1995 ; 2003)$ and Mohammadi et al. (2009) who also reported similar environmental and G x E effects. Significant G x E has been reported by Comstock and Moll, (1963) to reduce progress from selection of superior genotypes resulting from environmental effects that inhibits the expression of desired traits of genotypes evaluated across diverse environments, implying that the lack of significant $G$ $\mathrm{x} E$ mean squares observed for anthesis-silking interval, grain yield, plant height, root lodging and plant stand makes these traits more reliable as part of an index for the selection of superior genotypes as compared with the other traits measured in this study. Table 2 presents basic descriptive statistics [mean, median, standard deviation and coefficient of variation $(\mathrm{CV})$ ] of grain yield and the other traits measured at all the three locations. A high value of coefficient of variation was obtained for grain yield (27.86), anthesissilking interval (30.53), root lodging (47.39), stalk lodging (32.06), ear aspect (37.32) and husk cover (42.27). This result also revealed high levels of genotypic variability among the hybrids for grain yield, anthesis-silking interval, root lodging, stalk lodging, ear aspect and husk cover. The high levels of genetic variability observed for the traits studied with the exception of ear number per plant showed they could be utilized in selection criteria for yield improvement of the different genotypes.

\section{Correlations among traits measured}

The correlation studies showed that grain yield (GY) was highly significant $(\mathrm{p}<0.01)$ and positively correlated with ear aspect $(r=0.77)$, days to anthesis $(r=0.41)$, days to silking ( $r$ $=0.35)$, plant height $(\mathrm{r}=0.65)$, ear height $(\mathrm{r}=0.69)$, plant stand $(\mathrm{r}=0.48)$ and number of ears harvested per plot $(\mathrm{r}$ $=0.45$ ), implying that a hybrid with optimal ear appearance, longer days to anthesis and silking, taller plants, higher ear placement, and large number of plant stand and ears harvest- 
Table 1. Mean squares derived from combined analysis of variance of measured traits of 100 extra-early maturing maize hybrids evaluated at three locations in the deciduous forest and forestsavannah transitional zones of Ghana in 2011 rainy season.

\begin{tabular}{|c|c|c|c|c|c|c|c|c|}
\hline Source of variation & $\mathrm{DF}$ & $\begin{array}{c}\text { Grain yield (t ha- } \\
1)\end{array}$ & $\begin{array}{l}\text { Days to } \\
\text { silking }\end{array}$ & $\begin{array}{l}\text { Days to } \\
\text { anthesis }\end{array}$ & $\begin{array}{c}\text { Anthesis-silking } \\
\text { interval }\end{array}$ & Ear height $(\mathrm{cm})$ & Plant height $(\mathrm{cm})$ & Root lodging \\
\hline Environment & 2 & $87.27^{* *}$ & $198.91^{* *}$ & $419.66^{* *}$ & $604.87^{* *}$ & $37021.17^{* *}$ & $82314.59^{* * *}$ & $61.65^{* *}$ \\
\hline Reps(Environment) & 3 & $12.47^{* *}$ & $31.35^{* *}$ & $40.95^{* *}$ & $2.48^{\mathrm{ns}}$ & $1889.12^{* *}$ & $3463.34^{* *}$ & $1.41^{\mathrm{ns}}$ \\
\hline Blocks (Environment*Reps) & 54 & $1.96^{* * *}$ & $6.20^{* *}$ & $5.57^{* *}$ & $1.70^{\mathrm{ns}}$ & $255.24^{* *}$ & $471.36^{* *}$ & $1.74^{*}$ \\
\hline Genotype & 99 & $5.45 * *$ & $18.53^{* *}$ & $16.24^{* *}$ & $1.87^{*}$ & $497.58^{* *}$ & $944.57^{* *}$ & $2.45^{* *}$ \\
\hline Environment*Genotype & 198 & $0.84^{\mathrm{ns}}$ & $5.03^{* *}$ & $4.14^{* *}$ & $1.56^{\mathrm{ns}}$ & $87.55^{* *}$ & $172.59^{\mathrm{ns}}$ & $1.54^{\mathrm{ns}}$ \\
\hline Error & 243 & 0.75 & 2.17 & 2.37 & 1.42 & 61.78 & 166.86 & 1.23 \\
\hline \multicolumn{9}{|c|}{$\begin{array}{l}\text { Rep is Replication; BLK is Block; }{ }^{*} \mathrm{P} \leq 0.05, * * \mathrm{P} \leq 0.01 \text {, ns = not significant, respectively } \\
\text { Table } 1 \text { cont'd }\end{array}$} \\
\hline Source of variation & $\mathrm{DF}$ & stalk lodging & Husk cover & Plant stand & \multicolumn{2}{|c|}{$\begin{array}{c}\text { Number of ears harvested per } \\
\text { plot }\end{array}$} & number per plant & Ear aspect \\
\hline Environment & 2 & $1175.50^{* * *}$ & $63.92^{* *}$ & $678.97^{* * *}$ & \multicolumn{2}{|c|}{$269.02^{* *}$} & $0.35^{* *}$ & $3.23^{* * *}$ \\
\hline Reps(Environment) & 3 & $18.71^{* *}$ & $0.12^{\text {ns }}$ & $13.87^{\mathrm{ns}}$ & \multicolumn{2}{|c|}{$34.66^{*}$} & $0.02^{\mathrm{ns}}$ & $0.25^{*}$ \\
\hline Blocks (Environment*Reps) & 54 & $4.75^{* *}$ & $0.04^{\mathrm{ns}}$ & $8.72^{\mathrm{ns}}$ & \multicolumn{2}{|c|}{$10.25^{\mathrm{ns}}$} & $0.02^{\mathrm{ns}}$ & $0.17^{* *}$ \\
\hline Genotype & 99 & $5.36^{* *}$ & $0.09^{* *}$ & $17.25^{* *}$ & \multicolumn{2}{|c|}{$23.13^{* *}$} & $0.02^{\mathrm{ns}}$ & $0.25^{* *}$ \\
\hline Environment*Genotype & 198 & $4.07^{* * *}$ & $0.06^{* *}$ & $8.98^{\mathrm{ns}}$ & \multicolumn{2}{|c|}{$10.42^{* *}$} & $0.03^{* *}$ & $0.12^{*}$ \\
\hline Error & 243 & 2.54 & 0.04 & 7.34 & \multicolumn{2}{|c|}{7.50} & 0.02 & 0.09 \\
\hline
\end{tabular}

Rep is Replication; BLK is Block; * $\mathrm{P} \leq 0.05, * * \mathrm{P} \leq 0.01$, ns $=$ not significant, respectively.

Table 2. Descriptive statistics of grain yield and other agronomic traits measured in the study.

\begin{tabular}{|c|c|c|c|c|c|c|}
\hline Trait & Mean & Median & Maximum & Minimum & Standard deviation & $\mathrm{CV}(\%)$ \\
\hline Grain yield (t/ha) & 5.20 & 5.14 & 11.33 & 0.67 & 1.45 & 27.86 \\
\hline Days to anthesis & 45.15 & 45.00 & 52.00 & 35.00 & 2.77 & 6.14 \\
\hline Days to silking & 47.65 & 48.00 & 59.00 & 37.00 & 2.84 & 5.82 \\
\hline Anthesis-silking interval & 2.54 & 3.00 & 10.00 & 0.00 & 1.79 & 30.53 \\
\hline Number of ears harvested per plot & 22.07 & 23.00 & 38.00 & 9.00 & 3.61 & 16.38 \\
\hline Plant stand & 22.19 & 23.00 & 35.00 & 8.00 & 3.53 & 15.89 \\
\hline Ear number per plant & 1.01 & 1.00 & 2.00 & 0.52 & 0.16 & 15.85 \\
\hline Ear height $(\mathrm{cm})$ & 92.41 & 92.00 & 147.00 & 41.00 & 17.75 & 19.20 \\
\hline Plant height $(\mathrm{cm})$ & 183.50 & 185.00 & 264.00 & 95.00 & 25.81 & 14.07 \\
\hline Root lodging & 1.27 & 1.00 & 9.00 & 0.00 & 1.37 & 47.39 \\
\hline Stalk lodging & 2.57 & 2.00 & 16.00 & 0.00 & 2.80 & 32.06 \\
\hline Ear aspect & 2.15 & 2.00 & 4.00 & 1.00 & 0.73 & 34.20 \\
\hline Husk cover & 1.80 & 1.00 & 4.00 & 1.00 & 0.96 & 42.27 \\
\hline
\end{tabular}




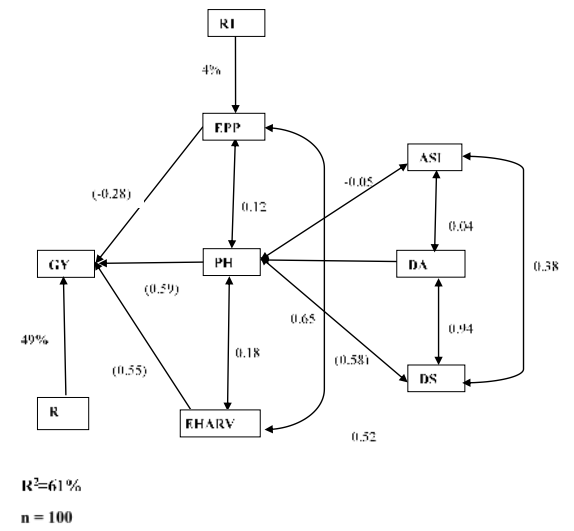

Fig 1. Path analysis diagram showing the contribution of number of ears harvested per plot (EHARV), plant height (PH), ear number per plant (EPP), anthesis-silking interval (ASI), days to anthesis (DA) and days to silking (DS) to grain yield (GY) formation. $\mathrm{n}_{-}$ sample size; $R_{-}$residual; $\mathrm{R}^{2}$ _coefficient of determination.

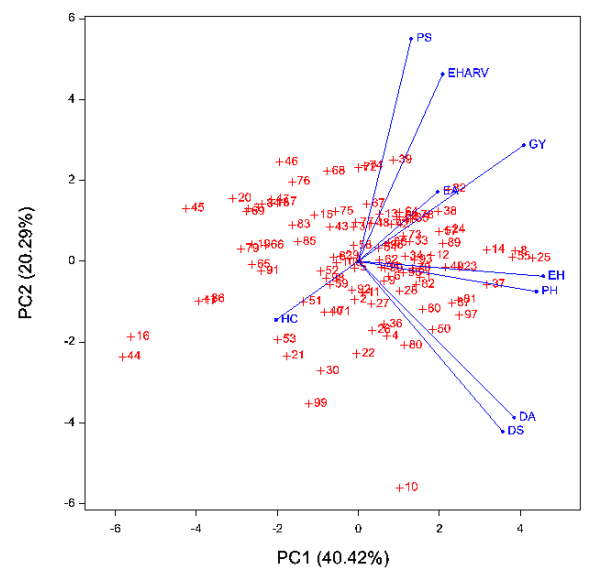

Fig 2. Principal component biplot of yield components of 100 extra-early maturing maize hybrids (names of entry codes are given in Supplementary Table 1) evaluated at three locations in Ghana. DA_days to anthesis; DS _days to silking; EA _ear aspect; EH _ear height; EHARV_number of ears harvested per plot; GY_ grain yield: HC_husk cover; PH_plant height; PS_ plant stand: RL_root lodging; SL_stalk lodging

ed possess high yield potential. The high correlation between grain yield and, plant and ear heights is also reported by Fakorede et al. (2011); khavari et al. (2011); Ashofteh et al. (2012) and Filipovic et al. (2014).

Grain yield was also negatively and significantly correlated with husk cover $(\mathrm{r}=-0.31)$ and ear number per plant $(\mathrm{r}=-$ 0.15 ) (Table 3). This result suggests that a hybrid with poor score for husk cover and larger ear number per plant is likely to have low grain yield. An earlier report by Badu-Apraku et al. (2012), showed similar findings except for the negative correlation between grain yield and ear number per plant. The differences in results could be due to the environmental conditions (drought and low soil nitrogen environments) under which their experiments were conducted as against the environment (favourable condition) that was used in this study. Prolificacy in maize (ability of a variety to produce more than one ear per plant) has been reported to be useful in stressful environments (higher plant densities, low soil fertility and moisture stress) (Zuber and Grogan, 1956; Russell and Eberhart, 1968), and of limited importance under favourable environments (Russell, 1968; Otegui, 1995). Nonetheless, under both stressful and favourable environments some non-prolific varieties have been found to produce higher grain yields than those with prolific tendencies (Brathwaite and Brathwaite, 2002). According to Durieux et al. (1993), a prolific variety has a yield advantage over a non-prolific variety only when it is able to develop larger apical ear. However, prolific varieties are sometimes limited in yield potential in favourable environments because the development of apical ears is restricted by the growth activity of the second ear (Russell, 1968). This may have been the cause of yield reduction associated with increasing ear number per plant as observed among the set of hybrids tested in this study.

The results also showed highly significant interrelationships between the following pairs of traits: Plant height and ear height $(\mathrm{r}=0.88)$; Ear height and days to anthesis $(r=0.63)$; Days to anthesis and days to silking $(r=$ $0.94)$; Plant height and days to anthesis $(r=0.58)$; Days to silking and plant height $(\mathrm{r}=052)$; Ear height and days to silking $(r=0.57)$; Ear aspect and ear height $(r=0.60)$; Ear aspect and plant height $(\mathrm{r}=0.69)$ and ear aspect and number of ears harvested per plot (Table 3). Mashark et al. (2004) reported similar significant positive correlation among days to silking, days to anthesis, ear height and plant height. Based on these results, it is important to note that among all the traits studied, ear aspect $(r=0.77)$ had the highest influence on grain yield followed by ear height $(r=0.69)$ and plant height $(r=0.65)$, which suggested that ear aspect, plant and ear heights determine to a great extent, the grain yield of the hybrids tested, making them important traits to consider in 
Table 3. Pearson coefficients of correlation between pairs of measured agronomic traits of 100 extra-early maturing maize genotypes evaluated at three locations in the deciduous forest and forest-savannah transition zones of Ghana in 2011 rainy season.

\begin{tabular}{|c|c|c|c|c|c|c|c|c|c|c|c|c|c|}
\hline Traits & GY & ASI & EA & DS & EH & EPP & EHARV & $\mathrm{HC}$ & PS & $\mathrm{PH}$ & DA & RL & SL \\
\hline ASI & $-0.09^{\mathrm{ns}}$ & - & & & & & & & & & & & \\
\hline EA & $0.77^{* *}$ & $-0.33^{\text {ns }}$ & - & & & & & & & & & & \\
\hline DS & $0.35^{* *}$ & $0.38^{* *}$ & $0.05^{*}$ & - & & & & & & & & & \\
\hline EH & $0.69^{* *}$ & $-0.02^{\mathrm{ns}}$ & $0.60^{\text {*** }}$ & $0.57^{* *}$ & - & & & & & & & & \\
\hline EPP & $-0.15^{*}$ & $-0.13^{\text {ns }}$ & $-0.01^{*}$ & $0.13^{\text {ns }}$ & $0.18^{\mathrm{ns}}$ & - & & & & & & & \\
\hline EHARV & $0.48^{* *}$ & $-0.19^{\mathrm{ns}}$ & $0.55^{* *}$ & $0.03^{\mathrm{ns}}$ & $0.31^{* * *}$ & $0.65^{* *}$ & - & & & & & & \\
\hline $\mathrm{HC}$ & $-0.31^{* *}$ & $0.25^{* *}$ & $-0.56^{* *}$ & $-0.08^{\text {ns }}$ & $-0.25^{* *}$ & $-0.27^{* *}$ & $-0.23^{*}$ & - & & & & & \\
\hline PS & $0.45^{* *}$ & $-0.05^{\mathrm{ns}}$ & $0.35^{* *}$ & $-0.11^{\mathrm{ns}}$ & $0.17^{\mathrm{ns}}$ & $-0.32^{* *}$ & $0.49^{* * *}$ & $-0.01^{\mathrm{ns}}$ & - & & & & \\
\hline $\mathrm{PH}$ & $0.65^{* *}$ & $-0.05^{\mathrm{ns}}$ & $0.69^{* *}$ & $0.52^{* *}$ & $0.88^{* *}$ & $0.12^{\mathrm{ns}}$ & $0.18^{\mathrm{ns}}$ & $-0.29^{* *}$ & $0.07^{\mathrm{ns}}$ & - & & & \\
\hline DA & $0.41^{* *}$ & $0.04^{\mathrm{ns}}$ & $0.18^{* *}$ & $0.94^{* * *}$ & $0.63^{\text {** }}$ & $0.19^{\mathrm{ns}}$ & $0.10^{\mathrm{ns}}$ & $-0.18^{\mathrm{ns}}$ & $-0.10^{* *}$ & $0.58^{* *}$ & - & & \\
\hline RL & $-0.01^{\mathrm{ns}}$ & $0.04^{\mathrm{ns}}$ & $-0.05^{\mathrm{ns}}$ & $0.12^{\mathrm{ns}}$ & $0.04^{\mathrm{ns}}$ & $-0.05^{\mathrm{ns}}$ & $-0.23^{*}$ & $-0.01^{\mathrm{ns}}$ & $-0.17^{\mathrm{ns}}$ & $0.13^{\text {ns }}$ & $0.11^{\mathrm{ns}}$ & - & \\
\hline SL & $-0.08^{\mathrm{ns}}$ & $0.12^{\mathrm{ns}}$ & $0.02^{\mathrm{ns}}$ & $0.17^{\mathrm{ns}}$ & $0.11^{\mathrm{ns}}$ & $-0.10^{\mathrm{ns}}$ & $-0.11^{\mathrm{ns}}$ & $0.03^{\mathrm{ns}}$ & $-0.02^{\mathrm{ns}}$ & $0.11^{\mathrm{ns}}$ & $0.14^{\mathrm{ns}}$ & $0.35^{* *}$ & - \\
\hline
\end{tabular}

Rep is Replication; BLK is Block; *P $\leq 0.05,{ }^{* *} \mathrm{P} \leq 0.01$, ns = not significant, respectively. ASI_anthesis-silking interval; DA__days to anthesis; DS_days to silking; EA_ear aspect; EH_ear height; EHARV_number of ears harvested per plot: EPP_ear number per plant; GY_ grain yield: $\mathrm{HC} \_$husk cover; PH_plant height; PS_ plant stand: RL_root lodging; SL_stalk lodging

Table 4. Factor loadings of grain yield and agronomic traits of 100 extra-early maturing maize hybrids evaluated at three locations in the deciduous forest and forest-savannah transition zones of Ghana in 2011 rainy season.

\begin{tabular}{|c|c|c|c|c|}
\hline \multirow{2}{*}{ Traits } & \multirow{2}{*}{ Communities } & \multicolumn{3}{|c|}{ Factor loading } \\
\hline & & 1 & 2 & 3 \\
\hline Days to anthesis & 0.34 & 0.57 & 0.07 & 0.09 \\
\hline Days to silking & 0.36 & 0.58 & 0.09 & 0.10 \\
\hline Ear aspect & 0.76 & -0.12 & 0.10 & -0.86 \\
\hline Ear height & 0.22 & 0.40 & -0.17 & -0.16 \\
\hline Number of ears harvested & 0.46 & 0.00 & -0.61 & 0.21 \\
\hline Grain yield & 0.28 & 0.17 & -0.39 & -0.32 \\
\hline Plant height & 0.22 & 0.36 & -0.05 & -0.27 \\
\hline Plant stand & 0.49 & -0.11 & -0.66 & -0.05 \\
\hline Husk cover & 0.87 & 0.03 & -0.02 & 0.02 \\
\hline$\%$ variance explained & & 42.40 & 20.29 & 11.95 \\
\hline \% Cumulative variance & & 42.40 & 62.69 & 74.64 \\
\hline
\end{tabular}

*values in bold indicate the most relevant character that contributed to the variation of the particular component. 
breeding and selection of extra-early maturing maize hybrids in the target environments. Ear aspect, plant height, ear height, days to silking, days to anthesis and number of ears harvested per plot were positively correlated with grain yield and also positively correlated to each other. The strong correlation observed among these traits reveals the existence of collinearity in the data set, which may have affected the exact expression of the influence of each trait on grain yield of the hybrids. In the study, it was observed that an increase in number of ears harvested per plot and days to silking promoted higher grain yield, however, the interrelationships between these two traits and certain traits seem to have adverse effects on grain yield. For instance, although, ear number per plant is positively correlated to number of ears harvested, at the same time it is negatively correlated to grain yield (Table 3). This means that as ear number per plant increases, number of ears harvested per plot increases and as the ear number per plant increases grain yield decreases. Also, days to silking had significantly positive effects on grain yield and anthesis-silking interval, suggesting that the longer it takes a hybrid to silk the higher the grain yield, but at the same time higher anthesis-silking interval adversely affects the grain yield. These results show how such interrelationship among some yield-related traits must have masked the effects of others on grain yield formation. In such situations, simple correlation studies may be insufficient to explain the associations in a way that will enable breeders know the traits to concentrate on during selection. Similar findings on multicollinearity of yield components have been reported in different crops including date palm (Phoenix Dactylifera L) (Odewale et al., 2013) and bambara groundnut (Vigna subterranean) (Ofori, 1996).

\section{Sequential path analysis of relationships among yield and yield-related traits across locations}

The sequential stepwise multiple regression method used in this study reduced the number of collinear variables by selecting from the whole set of yield-related traits a set of traits which influence yield the most. Number of ears harvested per plot (0.55), plant height (0.59) and ear number per plant $(-0.28)$ were identified as traits with high direct effects on grain yield. Together, these traits contributed $61 \%$ of the total variation in grain yield (Fig 1). This results implies that a larger yield response can be obtained if selection is based on plant height, number of ears harvested per plot and ear number per plant as compared to selection based on the other yield-related traits. Filipovic et al. (2014) reported highly significant genetic and phenotypic direct effects of plant height on grain yield. Also, plant height was reported by Badu-Apraku et al. (2012) to have a high significant influence on grain yield under drought. Days to silking (0.52), days to anthesis (0.58) and anthesis-silking interval $(-0.05)$ were identified as traits with indirect effects on grain yield via plant height (Fig 1), suggesting that improvement in yield could be achieve indirectly by simultaneously selecting hybrids with increased plant height, longer days to anthesis and silking, and reduced anthesissilking interval. The identified traits (plant height, number of ears harvested per plot, ear number per plant, days to anthesis and silking and anthesis-silking interval) with the greatest influence on grain yield will provide breeders with a set of key traits to target in selection programmes to make the most progress in grain yield improvement instead of selection based on grain yield alone.

\section{Factor analysis}

Figure 2 presents the genotype by trait principal component biplot showing the interrelationship among traits measured across the three locations. In the biplot display, the rays connecting the traits to the biplot origin are described as trait vectors. The cosine of the angle between two vectors approximates the correlation between the traits they represent (Kroonenberg, 1995).The closer the angle is to 90 degrees, the stronger the correlation. An angle of 0 or 180 degrees reflects a correlation of 1 or -1 , respectively. The biplot revealed a positive correlation between grain yield and ear aspect, plant stand, number of ears harvested per plot, ear and plant heights. Also, grain yield had a strong negative correlation with husk cover (Fig 2). Furthermore, the biplot revealed a strong positive correlation between grain yield and ear aspect; between plant stand and number of ears harvested per plot; between ear height and plant height: between days to silking and days to anthesis, indicating that information obtained on one of these traits may be sufficient to provide reliable information on the genotypes. Factor analysis was performed in order to better understand the common structure observed among yield components as well as their contribution to the formation of principal factors that define yield. Three main factors were extracted from principal component analysis of nine yield-related traits (days to anthesis, days to silking, ear aspect, number of ears harvested per plot, grain yield, plant height, ear height, plant stand and husk cover). The proportions of the total variance explained by each of the three factors were $42.40 \%, 20.29 \%$ and $11.95 \%$, respectively (Table 4 ). Together, the three factors accounted for $74.64 \%$ of the total variation observed among the hybrids. Factor loadings greater than or equal to 0.30 were considered as the point where selected traits made significant contribution to the formation of a factor. The first factor was positively correlated to days to silking (0.58), days to anthesis $(0.57)$, ear height $(0.40)$ and plant height $(0.36)$. This factor was referred to as the flowering component. The second factor was negatively correlated to grain yield (-0.39), plant stand (-0.66) and number of ears harvested per plot ($0.61)$. This factor was referred to as the reproductive component. The third factor had negative correlation to ear aspect (-0.86) and grain yield (-0.32). The third factor was called the ear appearance component.

Traits loaded on the first two factors were considered to have influenced the data set the most. These traits included days to silking, days to anthesis, ear height, grain yield, plant stand and number of ears harvested per plot. Since grain yield is equally correlated with the second (0.39) and third (0.32) factors, there is an association between grain yield and the other traits that define these two factors (Table 4). Therefore, it can be concluded that plant stand, number of ears harvested per plot and ear aspect may be very important in selecting extra-early maturing maize hybrids for superior grain yield. This result is in agreement with a report by Tollenaar, (1992) which suggests that since early maturing varieties are normally smaller, produce less leaves, have lower leaf area per plant and presents fewer self-shading problems than late maturing ones, it is important to have a greater number of plants per area for early maturing hybrids to generate the leaf area index that provides maximum interception of solar radiation to attain maximum grain yield.

Both path and factor analyses identified the following groups of traits to be related: days to anthesis, days to silking, plant height and grain yield and, number of ears harvested per plot and grain yield (Table 4 and Fig 1). These result revealed the existence of common structure of yield 
components and the possibility of explaining the variability observed in one component based on other remaining components studied. In this study, the degree of prediction of the variability of one trait based on the other traits ranged between $87.00 \%$ for husk cover to $22.00 \%$ for plant and ear heights. Only $28.00 \%$ of variability in grain yield of the hybrids could be explained by the other remaining traits (Table 4). This indicates that grain yield was influenced by other external factors aside the traits studied. Apparently, the results of the combined ANOVA across locations for grain yield showed large mean square for environment (87.27) as compared to genotypic mean square (5.45) (Table 2). This suggests that prevailing environmental conditions at the evaluation sites during the period of this experiment may have been the greatest cause of variability observed among the hybrids for grain yield. Several field evaluations of maize varieties have revealed existence of environmental influences on yield and many important yield components (Filipovic et al., 2013; Fakorede et al., 2011; Badu-Apraku et al., 2012) and as such the need to identify traits associated with improved grain yield performance under target growing conditions.

A comparison of the results of all the multivariate analyses performed in this study revealed a strong association between grain yield and ear aspect, except for path analysis which did not identify ear aspect as a trait with significant influence on grain yield. Failure of the path analysis to identify ear aspect as an important contributor to grain yield, may be attributed to the differences in the different statistics used by the two methods. Path analysis uses partial regression coefficients while the other methods (simple correlation, principal component biplot and factor analysis) uses correlation among traits to identify traits of importance. Also, it is important to note that whiles path analysis recognizes multicollinearity among traits, the other methods like the biplot only displays the relationship among traits graphically, based on their correlations (Badu-Apraku et al., 2012). For this reason, ear aspect may have been eliminated from the stepwise regression analyses due to the high correlation between ear aspect and plant stand, number of ears harvested per plot, plant and ear heights, as showed by the biplot.

\section{Materials and Methods}

\section{Field evaluation}

The experiment was conducted during the 2011 major season at three locations namely, Fumesua ( $7038^{\prime} \mathrm{N}, 307^{\prime} \mathrm{E}, 60 \mathrm{~m}$ altitude), Ejura ( $7038^{\prime} \mathrm{N}, 1037^{\prime} \mathrm{E}, 229 \mathrm{~m}$ altitude) and Kpeve (30 20'N, 0017'E, $69 \mathrm{~m}$ altitude) in the deciduous forest and forest-Savannah transition zones of Ghana, respectively. The germplasm used for the study were 100 extra-early maturing maize varieties (maize varieties that reaches physiological maturity within 80 to 85 days), comprising of 98 single-cross hybrids and two (2) open pollinated varieties (Akposoe and Dodzi) as checks.

A standard protocol was adopted at each site during the period of evaluation. Evaluations were done under rain-fed conditions. The genotypes were planted in $10 \times 10$ lattice design with two replications at each location. The genotypes were grown in 2-row plots of $5 \mathrm{~m}$ long, at an inter-row spacing of $75 \mathrm{~cm}$ and an intra-row spacing of $40 \mathrm{~cm}$. Three seeds were planted per hill, and later the seedlings were thinned to two seedlings per hill at 4 to 5 leaf stage. Preemergence chemical weed control was practiced and comprised of an application of a combination of
Pendimethalin [N-(1-ethylpropyl)-3, 4-dimethyl-2, 6dinitrobenzenamine] and Gesaprim [2-chloro-4-(ethylamino)6-(isopropylamino)-s-triazine] at $1.5 \mathrm{~L} \mathrm{ha}^{-1}$ and $1.0 \mathrm{~L} \mathrm{ha}^{-1}$ a.i., respectively, at planting. Hand weeding was also done when necessary to control weeds during the growing period. NPK $15-15-15$ fertilizer was applied at the rate of $30 \mathrm{~kg} \mathrm{~N} \mathrm{ha}^{-1}, 60$ $\mathrm{kg} \mathrm{P}_{2} \mathrm{O}_{5} \mathrm{ha}^{-1}$ and $60 \mathrm{~kg} \mathrm{~K}_{2} \mathrm{O} \mathrm{ha}^{-1}$ as basal fertilizer at $1-2$ weeks after planting and top-dressed with additional $\mathrm{N}$ at 60 $\mathrm{kg} \mathrm{N} \mathrm{ha}^{-1}$ at four weeks after planting.

\section{Data collection}

Data were recorded at all the three locations for the following agronomic and morphological traits: days to anthesis (DA), days to silking (DS), plant height $(\mathrm{PH})$, ear height $(\mathrm{EH})$, root lodging (RL), stalk lodging (SL) and husk cover (HC). Plant height was measured as the distance from the base of the plant to the height of the flag leaf and ear height was measured as the distance from the base to the node bearing the uppermost ear. Days to anthesis and silking were calculated as the number of days from planting to when $50 \%$ of the plants had shed pollen and had emerged silks, respectively. Husk cover was rated on a scale of 1 to 5, where $1=$ husks tightly arranged and extended beyond the ear tip and $5=$ ear tips exposed. Anthesis-silking interval (ASI) was calculated as the difference between the number of days to silking and the number of days to anthesis. Root lodging (RL) was recorded as the number of plants leaning more than $30^{\circ}$ from the vertical axis, and stalk lodging (SL) as the number of plants broken at or below the highest ear node. At harvesting, plant stand (PS), number of ears harvested per plot (EHARV), ear aspect (EA), ear number per plant (EPP), field weight and grain moisture were measured per plot at all locations. Plant stand was recorded as the total number of plants harvested per each plot. Number of ears harvested per plot were recorded as the total number of ears harvested per each plot. Ear aspect was scored on a scale of 1 to 5, where 1 $=$ ears with undesirable features and $5=$ clean, uniform, large, and well-filled ears. Ear number per plant was obtained by dividing the total number of ears harvested by the plant stand per plot. Field weight was measured as the weight of harvested cobs per plot in kilograms. Moisture percentage of grains was measured using a moisture meter. Grain yield (GY) in each experimental plot was corrected and calculated in tonnes per hectare at $15 \%$ grain moisture based on $80 \%$ shelling percentage.

\section{Statistical analysis}

Analyses of variance (ANOVA) were conducted separately on plot basis for all the traits measured for each location followed by a combined analysis across the three locations using PROC GLM in SAS (SAS Institute, 2001).In the combined analysis of variance, genotypes were considered as fixed effects, while environments, replications, genotype by environment interaction and all other sources of variation were considered as random effects. Data on ear aspect and husk cover were transformed by natural logarithm function before analyses. Pearson coefficients of correlation were calculated using the genotype means of traits measured to determine the causal relationships among traits across the three test locations. Sequential stepwise multiple regressions by Mohammadi et al. (2003) was used to organize the predictor variables into first- and second-order paths based on their respective contributions to the total variation in grain yield (GY) with minimum collinearity. The PROC CORR procedure of SAS was used to compute the correlation 
coefficients and the PROC REG procedure for regression analysis. Also, the means of all the traits measured across the three locations were subjected to principal component analysis using correlation matrix procedure. Subsequently, factor analysis was performed using varimax rotation (Genstat, 2009).

\section{Conclusion}

The results of correlation studies of grain yield and the other agronomic traits revealed that grain yield correlated positively with ear aspect, days to anthesis, days to silking, plant height, ear height, number of ears harvested per plot and plant stand, but negatively correlated to husk cover and ear number per plant. With exception of husk cover and ear number per plant, the other traits that correlated positively to grain yield were also strongly associated to each other throughout the study. Plant height, number of ears harvested per plot, plant stand and ear aspect identified by path and factor analyses to have the greatest influence on grain yield could be considered as reliable traits for selection for yield improvement of extra-early maturing hybrids. The magnitude of environmental variance observed was greater than genotypic variance for all traits measured showing pronounced effects of environment on the traits, which may limit the heritability of the identified traits as well as reduce the correspondence of their phenotypic and genetic correlations. Thus, in order to enhance the reliability of secondary traits in selecting hybrids with higher yield there is the need to identify such traits under environmental conditions in which the hybrids will be grown.

\section{Acknowledgments}

The authors are grateful to the Alliance for a Green Revolution in Africa (AGRA), for providing funding for this research. The opinions expressed herein are those of the author(s) and do not necessarily reflect the views of AGRA. Also, we thank Dr. Joseph Adjebeng- Danquah of CSIRSavanna Agricultural Research Institute for his excellent critique of an earlier draft of this paper.

\section{References}

Abozary Gasaforodi A (2002) Genetic and morphological diversity of correlation and data storage protein electrophoresis in rice varieties. MSc dissertation. Faculty of Agriculture, Guilan University. P 119.

Agrama, HAS (1996) Sequential path analysis of grain yield and its components in maize. Plant Breeding. 115: 343346.

Ashofteh BM, Siah Sar BA, Khavari Khrasani S, Golbashy M, Mahdi Nejad N, Ali Zade A (2010) Effects of genotype by environment interactions on morphological traits, yield and yield components of new grain corn (Zea mays L.) varieties. J Agroecology. 2(1): 136-145.

Badu-Apraku B, Abamu FJ, Menkir A, Fakorede MAB, Obeng-Antwi K (2003) Genotype by environment interactions in the regional early variety trials in west and central Africa. Maydica. 48(2), 93-104.

Badu-Apraku B, Akinwale RO, Franco J, Oyekunle M (2012) Assessment of reliability of secondary traits in selecting for improved grain yield in drought and low-nitrogen environments. Crop Sci. 52(5): 2050-2062.

Badu-Apraku B, Fajemisin JM, Diallo AO (1995) The performance of early and extra-early varieties across environments in West and Central Africa. In: Badu-Apraku
B, Akoroda M O, Ouedraogo M, Quin F M (eds) Contributing to food self-sufficiency: Maize research and development in West and Central Africa, Proceedings of a regional maize workshop, 29 May-2 June 1995: Cotonou, Benin republic. p 149-159

Badu-Apraku B, Oyekunle M, Fakorede MAB, Vroh I, Akinwale RO and Aderounmu M (2013) Combining ability, heterotic patterns and genetic diversity of extraearly yellow inbreds under contrasting environments. Euphytica. 192 (3):413-433.

Badu-Apraku, B., Akinwale RO, Ajala SO, Menkir A, Fakorede MAB, Oyekunle M (2011). Relationships among traits of tropical early maize cultivars in contrasting environments. Agron J. 103:717-729.

Bänziger M, Lafitte HR (1997) Efficiency of secondary traits for improving maize for low-nitrogen target environments. Crop Sci. 37:1110-1117.

Bhatt GM (1973) Significance of path coefficient analysis determining the nature of character association. Euphytica. 22:338-343.

Brathwaite O, Brathwaite RAL (2002) Multiple ear effects on yield of maize varieties under tropical wet and dry conditions. Maydica. 47:115-120.

Chapman SC, Edmeades GO (1999) Selection improves drought tolerance in tropical maize populations. II. Direct and correlated responses among secondary traits. Crop Sci. 39:1315-1324.

Comstock RE, Moll RH (1963) Genotype-environment interactions. Symposium on Statistical Genetics and Plant Breeding, NAS-NRC pub. 982:164-196.

Durieux RP, Kamprath EP, Moll RH (1993) Yield contribution of apical and sub-apical ears in prolific and non-prolific corn. Agron J. 85: 606-610.

Edmeades GO, Bolanos J, Bänziger M, Ribaut JM, White JW, Reynolds MP, Lafitte HR (1998) Improving crop yields under water deficits in the tropics. In: Chopra VL, Singh RB, Varma A (eds): crop productivity and sustainability - Shaping the Future. 2nd International Crop Science Congress, New Delhi, Oxford and IBH, p 437451.

Edmeades GO, Bolaños J, Chapman SC (1997) Value of secondary traits in selecting for drought tolerance in tropical maize. In Edmeades GO, Bänziger M, Mickelson HR, Peña-Valdivia CB (eds.) Developing drought and low $\mathrm{n}$ tolerant maize. Proceedings of a Symposium, 25-29 March 1996, CIMMYT, El Batán, Mexico, D.F. p 222-234.

Ezeaku IE, Mohammed SG (2006) Character association and path analysis in grain sorghum. Afr J Biotech. 5(14): 13371340.

Fakorede MAB, Oluwaranti A, Badu-Apraku B, Menkir A (2011) Trait association of maize varieties in contrasting seasons in the rainforest of southwest Nigeria. African crop science conference proceedings. Vol. 10. p $541-544$.

FAO Statistics (2014) Website: http://www.faostat.fao.org Check on $27^{\text {th }}$ April 2015.

Filipovic M, Babic M, Delic N, Bekavac G, Babic V (2014) Determination of relevant breeding criteria by the path and factor analysis in maize. Genetika. 46 (1): 49-58.

Filipovic M, Srdic J, Simic M, Videnovic Ž, Radenovic C, Dumanovic Z, Jovanovic Ž. (2013) Potential of early maturity flint and dent maize hybrids at higher altitudes. Rom Agric Res. 30: 117-124.

García Del Moral LF, Ramos JM, Jimenez MP (1999) Ontogenetic approach to grain production in spring Barley based on path- coefficient analysis. Crop Sci. 31: 11791185 . 
García Del Moral LF, RharrabtI Y, Villegas D, Royo C (2003) Evaluation of grain yield and its components in durum wheat under Mediterranean conditions: An ontogenic approach. Agron J. 95: 266-274.

GenStat, (2006) Guide to GenStat release 9 - part 2: statistics, by the Genstat committee. Payne RW (Ed). VSN international publication. ISBN 1-904375-26-X.

Hair JR, Anderson RE, Tatham RL, Black WC (1995) Multivariate data analysis with readings. Prentice Hall, Englewood, NY, USA.

Hoe JS, Kim DS (2004) A new method of ozone forecasting using fuzzy expert and neural network systems. Sci Total Environ. 325:221-237.

Index M (2015) Ghana corn production by year. Website: http/www.indexmumdi_corn_agriculture_country_gh_com modity_corn_gr.pdf. Checked on $21^{\text {st }}$ June, 2015.

Khavari Khrasani S1, Mostafavi KH, Zandipour E., Heidarian A. ((2011) Multivariate analysis of agronomic traits of new corn hybrids (Zea mays L.). Int J Agri Sci. 1(6): 314-322.

Kroonenberg PM (1995) Introduction to biplots for $\mathrm{G} \times \mathrm{E}$ tables. Department of Mathematics, Research Report 51. University of Queensland, Australia. [Online] Available: http://three-mode.leidenuniv.nl/document/biplot.pdf.

Kumar MVN, Kumar SS (2000) Studies on character association and path coefficients for grain yield and oil content in maize (Zea mays L.). Ann Agric Res. 21:73-8.

Maman N, Mason SC, Lyon DJ, Dhungana P (2004). Yield components of pearl millet and grain sorghum across environments in the central Great Plains. Crop Sci. 44: 2138-2145.

Mashark SA, Sallah PKY, Sarfo-kantanka O (2004) Evaluation of maturity and its correlated traits in an unadapted F2 maize population. J Sci Tech. 24 (2): 13-21.

Menkir A, Akintunde AO (2001) Evaluation of the performance of maize hybrids, improved open-pollinated and farmers' local varieties under well-watered and drought stress conditions. Maydica. 46:227-238.

Millennium Development Authority (2010) Available at http://www.mcc.gov/documents/investmentopps/bomghana-english-grain.pdf

Ministry of Food and Agriculture (MOFA) (2013) Facts and figures. In: Agriculture in Ghana. Statistics research and information directorate (SRID). $\mathrm{p} 13$.

Mohammadi R, Amri A, Haghparast R, Sadeghzadeh D, Armion M, Ahmadi MBM (2009) Pattern analysis of genotype by environment interaction for grain yield in durum wheat. J Agr Sci. 147(5): 537-545.

Mohammadi SA, Prasanna BM, Singh NN (2003) Sequential path model for determining interrelationship among grain yield and related characters in maize. Crop Sci. 43: 16901697.

Odewale JO, Agho C, Ataga CD, Odiowaya G, Hamza A, Uwadiae EO, Ahanon MJ (2013) Study of some fruit and seed traits relationship and assessment of multicollinearity in date palm (Phoenix Dactylifera L) accessions of Nigeria by correlation and principal component analysis. Gr J Agric Sci. 3 (2): 164-175.

Ofori I (1996) Correlation and path-coefficient analysis of components of seed yield in Bambara groundnut (Vigna subterranean). Euphytica. 91: 103-107.
Otegui ME (1995) Prolificacy and grain yield in modern Argentinian maize hybrids. Maydica. 40:371-376.

Quarrie SA, Pekic Quarrie S, Radosevic R, Rancic D, Kaminska A, Barnes JD, Leverington M, Ceoloni C, Dodig D (2006) Dissecting a wheat QTL for yield present in a range of environments: from the QTL to candidate genes. J Exp Bot. 57 (11): 2627-2637.

Ross AJ (2002) Genetic analysis of ear length and correlated traits in maize: retrospective theses and dissertations. Paper 542. Hyyp://lib.dr.iastate.edu/rtd/542

Rummel RJ (1970) Understanding factor analysis: a summary of Rummel Applied's Factor Analysis. p 8-10.

Russell WA (1968) Testcross of one and two-ear type of Corn Belt maize inbreds. I. Performance of four plant stand densities. Crop sci. 8: 244-247.

Russell WA, Eberhart SA (1968) Testcrosses of one- and two-ear types of Corn Belt maize inbreds. II. Stability of performance in different environments. Crop Sci. 8: 248 251.

Samonte SOPB, Wilson TL, Tabien RE (2006). Maximum node production rate and main culm node number contributions to yield and yield-related traits in rice. Field Crops Res. 96: 313-319.

Samonte SOPB, Wison LT, McClung AM (1998) Path analysis of yield and yield related traits of fifteen diverse rice genotypes. Crop Sci. 38: 1130-1136.

SAS Institute (2001) Statistical Analysis Software (SAS) User's Guide, version 9.2. SAS Institute, Inc., Cary, NC.

Sharma S (1996) Applied multivariate techniques. John Wiley \& Sons, Inc., Canada.

Solymanzadeh H, Latifi N, Soltani A (2007) Phenological and physiological traits associated with grain yield of Canola cultivars under rain fed conditions. J Agric Sci Natur Resour. 14(5): 67-76.

Tollenaar M (1992) Is low plant density a stress in maize? Maydica. 37 (2): 305-311.

Wright S (1921) Correlation and causation. J Agric Res. 20:557-585.

Zuber MS, Grogan GO (1956) Rates of planting studies with corn. Mo AES Res bull. 610. 